Jurnal Diversita, 7 (1) Juni (2021) ISSN 2461-1263 (Print) ISSN 2580-6793 (Online)

DOI: https://doi.org/10.31289/diversita.v7i1.4228

Jurnal Diversita

Available online http://ojs.uma.ac.id/index.php/diversita

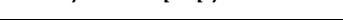

\title{
Model Partisipasi Masyarakat dengan Perspektif Psikologi pada Pelayanan Posyandu di Kota Malang dan Kota Madiun
}

\section{Community Participation Model with Psychological Perspective on Posyandu Services in Malang City and Madiun City}

\author{
Intan Rahmawati(1*), Tia Subekti(2) \& Irza Khurun'in(3) \\ Program Studi Psikologi, Universitas Brawijaya, Indonesia \\ Disubmit: 06 September 2020; Diproses: 10 September 2020; Diaccept: 26 April 2021; Dipublish: 02 Juni 2021 \\ *Corresponding author: E-mail: intanr@ub.ac.id
}

\begin{abstract}
Abstrak
Posyandu hadir sebagai Unit Kesehatan Berbasis Masyarakat yang dikelola dan diselenggarakan oleh, untuk, dan bersama masyarakat. Provinsi Jawa Timur menjadi salah satu provinsi di Indonesia yang aktif dalam melakukan inovasi pelayanan kesehatan masyarakat melalui Posyandu. Partisipasi masyarakat melalui Posyandu sebagai bentuk dari pembangunan kesehatan yang inklusif dengan melibatkan peran aktif masyarakat serta tidak meninggalkan nilai-nilai lokal. Penelitian ini bertujuan untuk mengetahui model partisipasi masyarakat pada pelayanan Posyandu di Posyandu Delima Kota Malang dan Posyandu Tanjung Kota Madiun. Metode penelitian yang digunakan adalah kualitatifdengan teknik purposive sampling, serta menggunakan interview mendalam, observasi, dan dokumentasi pada 2 informan. Data yang telah diperoleh dianalisis dengan menggunakan modifikasi metode StevickColaizzi-Keen dari Moustakas untuk menemukan dinamika partisipasi. Hasil penelitian ini menunjukkanadanya keterlibatan proses mental individu dalam kelompok yang melibatkan proses tanggung jawab bersama untuk mencapai tujuan kelompok yang diharapkan. Proses mental ini dipengaruhi oleh lingkungan, budaya, pengalaman, dan karakteristik organisasi, sehingga dapat menumbuhkan dan mengembangkan partisipasi individu dalam berinovasi yang dilatar belakangi oleh motivasi, ide, dorongan, gagasan, tekanan, dan kebutuhan.
\end{abstract}

Kata Kunci: Partisipasi Masyarakat, Perspektif Psikologi, Pelayanan Kesehatan, Posyandu

\begin{abstract}
Posyandu exists as a Community Based Health Unit that is managed and organized by, for and with the community. East Java Province is one of the provinces in Indonesia that is active in innovating public health services through Posyandu. Community participation through Posyandu as a form of inclusive health development by involving the active role of the community and not leaving local values. This study aims to determine the model of community participation in Posyandu services in Posyandu Delima Malang City and Posyandu Tanjung Madiun City. The research method used was qualitative with purposive sampling technique, and used in-depth interviews, observation, and documentation on 2 informants. The data obtained were analyzed using a modified Stevick-Colaizzi-Keen method from Moustakas to discover the dynamics of participation. The results of this study indicate the involvement of individual mental processes in groups that involve joint responsibility processes to achieve the expected group goals. This mental process is influenced by the environment, culture, experience, and organizational characteristics, so that it can foster and develop individual participation in innovation based on motivation, ideas, encouragement, ideas, pressures, and needs.
\end{abstract}

Keywords: Community Participation, Psychological Perspective, Health Services, Posyandu

How to Cite: Rahmawati,I., Subekti, T., \& Khurun'in, I. (2021), Model Partisipasi Masyarakat dengan Perspektif Psikologi, Jurnal Diversita, 7 (1): 1-11. 


\section{PENDAHULUAN}

Prevalensi status gizi buruk bayi di Indonesia belum mengalami perbaikan yang signifikan sejak tahun 2017. Tahun Tahun 2017 tercatat sebanyak 3,8\% bayi usia 0-59 bulan mengalami gizi buruk dan $14,00 \%$ mengalami gizi kurang, sehingga totalnya adalah 17,8\% (Kemenkes, 2018). Sementara itu status bayi usia 0-59 bulan yang mengalami gizi buruk pada 2018 sebanyak 3,8\% dan gizi kurang sebanyak $13,8 \%$ maka totalnya adalah $17,6 \%$ (Kemenkes, 2019). Selain gizi buruk pada bayi, kesehatan ibu hamil juga perlu mendapat perhatian khusus. Tahun 2015 terdapat $13,3 \%$ ibu hamil dengan resiko KEK (Kurang Energi Kronik), kemudian tahun 2016 meningkat menjadi 16,2\% dan menurun pada tahun 2017 menjadi 14,8\% (Kemenkes, 2018). Kondisi tersebut berbahaya karena bisa berdampak pada kelahiran premature, BBLR (Berat Badan Lahir Rendah), hingga kematian bayi.

Tingginya resiko pada ibu hamil dan bayi, maka diperlukan upaya-upaya guna meningkatkan kesehatan ibu hamil dan bayi salah satunya melalui pelayanan kesehatan di Posyandu (Pos Pelayanan Terpadu). Sesuai dengan Peraturan menteri Kesehatan Nomor 25 Tahun 2014 bahwa salah satu upaya untuk mencapai kesehatan anak secara terpadu, menyeluruh dan berkesinambungan adalah melalui Posyandu.

Jawa Timur termasuk salah satu provinsi yang giat melakukan inovasi dalam pelayanan kesehatan berbasis masyarakat melalui Posyandu. Jumlah Posyandu di Jawa Timur sampai dengan akhir tahun 2018 total Posyandu berjumlah 46.733. Strata Posyandu di Jawa Timur pada tahun 2018 terbanyak adalah Tingkat Purnama sebanyak 32.528 (70\%) dan sebanyak 7\% merupakan Posyandu Mandiri atau Posyandu dengan strata yang paling tinggi (Dinas Kesehatan Provinsi Jawa Timur, 2018). Maka, total posyandu Purnama Mandiri (Puri) kini mencapai $77 \%$ atau 36.044 Posyandu (Dinas Kesehatan Provinsi Jawa Timur, 2018). Salah satu upaya Pemerintah Provinsi Jawa Timur untuk menggalakkan pelayanan kesehatan berbasis masyarakat adalah melalui lomba Pelaksana Terbaik Kesatuan Gerak PKKdan Kesehatan Kategori Posyandu yang diadakan tiap tahun.

Partisipasi masyarakat melalui Posyandu sebagai bentuk dari pembangunan kesehatan yang inklusif dengan melibatkan peran aktif masyarakat serta tidak meninggalkan nilai-nilai lokal. Posyandu menjadi pelayanan kesehatan dari dan untuk masyarakat sekaligus yang paling dekat dengan masyarakat khususnya bagi ibu hamil dan bayi. Selain itu, Posyandu menjadi salah satu wadah keterlibatan masyarakat dalam meningkatkan status kesehatan khususnya untuk ibu dan bayi. Berdasarkan hal tersebut, menarik untuk melihat bagaimana dinamika partisipasi masyarakat terkait dengan pelayanan kesehatan melalui Posyandu.

\section{Partisipasi Masyarakat}

Pada sistem demokrasi, partisipasi masyarakat merupakan salah satu syarat wajib terwujudnya sebuah tatanan negara yang demokratis. Demokrasi dari asal katanya memiliki makna government by people yang berarti pemerintahan dari rakyat (Budiarjo, 2008). Partisipasi dalam kaitanya dengan demokrasi identik 
dengan sebutan partisipasi politik. Herbert McClosky menjelaskan partisipasi politik adalah kegiatan-kegiatan sukarela dari warga masyarakat melalui mana mereka mengambil bagian dalam proses pemilihan penguasa, dan secara langsung atau tidak langsung dalam proses pembentukan kebijakan umum (Budiarjo, 2008). Definisi tersebut sangat berkaitan dengan proses pemilu. Sementara itu Samuel P. Hutington memberikan pnejalasan partisipasi dengan definisi yang lebih umum yakni, partisipasi politik adalah kegiatan warga yang bertindak sebagai pribadi- pribadi, yang dimaksud untuk memengaruhi pembuatan keputusan oleh pemerintah (Budiarjo, 2008).

Budiardjo (2008) juga menjelaskan bahwa anggota masyarakat yang berpartisipasi dalam proses politik misalnya melalui pemberian suara atau kegiatan lain terdorong keyakinan bahwa melalui kegiatan bersama tersebut kepentingan mereka akan tersalur atau sekurang-kurangnya diperhatikan. Dengan kata lain mereka percaya bahwa kegiatan mereka mempunyai efek politik (political efficiacy). Tingkat keaktifan masyarakat dalam berpatisipasi tidak sama, hal ini melahirkan beberapa kategori partisipasi politik menurut Milbart dan Goel yaitu (1) Pemain (gladiator), (2) Penonton (spectator), dan (3) apatis.

Partisipasi masyarakat dalam definisi diatas cenderung fokus pada partisipasi pada tahapan pemilihan umum. Sementara itu peran serta masyarakat dalam pemerintahan yang demokratis tidak semata berkaitan dengan penggunaan hak pilih. Namun masyarakat juga dituntut untuk berperan dalam proses pemerintahan tersebut. Partisipasi dalam konteks ini sering disebut sebagai partisipasi publik. Partisipasi publik penting dilakukan dalam proses perencenaan, pembuatan, dan pelaksanaan kebijakan yang dibuat oleh pemerintah. Partisipasi publik yang demikian biasanya diwujudkan dalam berbagai kegiatan seperti diskusi di dalam ruang-ruang publik, melakuan pertemuanpertemuan publik, melakukan inisiatif, dan referendum (Marijan, 2015). Partisipasi dalam konteks ini berkaitan dengan sejauh mana peran masyarakat dalam mendukung kebijakan pemerintah. Mulai dari perencanaan kebijakan sampai pada tahap evaluasi kebijakan.

Pelayanan kesehatan Posyandu sebagai salah satu kebijakan pemerintah mensyaratkan partisipasi masyarakat dalam pelaksanaanya. Pada level implementasi tingkat keberhasilan program pemerintah bergantung pada sejauh mana masyarakat berperan aktif. Sebagai penerima layanan, dukungan masyarakat penting untuk menjalankan program dan juga memberikan umpan balik pada perbaikan kebijakan. Partisipasi masyarakat dalam pelayanan kesehatan Posyandu diwujudkan melalui beberapa kegiatan yaitu: aktif mengikuti kegiatan posyandu, kooperatif dan informatif pada petugas, memberikan sumbangan pemikiran maupun turut melaksanakan layanan yang inovatif, dan lain sebagainya.

\section{METODE PENELITIAN}

Penelitian ini menggunakan pendekatam kualitatif dengan tujuan untuk mengeksplorasi dan memahami makna melalui cara kerja analisis data 
secara induktif (Creswell, 2012) pada dinamika partisipasi masyarakat untuk pelayanan posyandu tanpa tercampuri oleh prasangka-prasangka atau opiniopini yang ada sebelumnya, sehingga lebih fokus pada individu, meliputi apa yang dipikirkan, dirasakan dan diperbuat masyarakat. Dengan ini, partisipasi masyarakat merupakan hasil eksplorasi dari interaksi berbagai variabel yang ada dalam diri individu dengan lingkungannya. Sumber data penelitian ini diambil dengan teknik purposive sampling pada ketua dua Posyandu terbaik di Jawa Timur yang masuk dalam nominasi yakni Posyandu Delima Kelurahan Madyopuro Kota Malang dan Posyandu Tanjung Kelurahan Kejuron Kota Madiun.

Sementara itu, teknik pengumpulan data penelitian ini menggunakan interview mendalam, observasi, dan dokumentasi. Peneliti menggunakan wawancara semi terstruktur untuk mendapatkan data-data yang berkaitan dengan partisipasi masyarakat dalam mengoptimalkan posyandu, sehingga dapat menjelaskan pola antar individu dengan program posyandu yang melibatkan proses kognitif, afektif, dan perilaku. Observasi digunakan peneliti untuk mengamati setiap kejadian serta simbol yang ada pada lingkungan penelitian. Dokumentasi juga digunakan dalam penelitian ini sebagai teknik pengumpulan data tertulis dan tidak tertulis yang dapat menguatkan fakta penelitian. Data yang telah didapatkan kemudian di analisis dengan menggunakan modifikasi metode StevickColaizzi-Keen dari Moustakas (1994).

\section{HASIL DAN PEMBAHASAN}

Informan yang menjadi data primer dalam penelitian ini adalah HT dan SM sebagai ketua posyandu untuk Posyandu Tanjung Kota Madiun dan Posyandu Delima Kota Malang.

Tabel 1. Informan Penelitian

\begin{tabular}{llll}
\hline No. & Nama & Keterangan & \\
\hline 1. & HT & $\begin{array}{l}\text { Ketua Posyandu } \\
\text { Kota Madiun }\end{array}$ \\
\hline 2. & SM & $\begin{array}{l}\text { Ketua Posyandu Delima Kota } \\
\text { Madiun }\end{array}$ \\
\hline
\end{tabular}

Sumber : hasil olah data penelitian

Kedua informan menyampaikan Pos Pelayanan Terpadu (Posyandu) merupakan salah satu pelayanan kesehatan berbasis swadaya masyarakat yang diwariskan oleh orde baru. Program ini di inisiasi oleh Presiden Soeharto pada tahun 1984. Setiap tahunnya pada tanggal 29 April diperingati sebagai hari posyandu.

Pada pelayananya posyandu diselenggarakan oleh kader perempuan dari warga desa atau kelurahan setempat yang dipilih secara sukarela. Layanan posyandu diberikan minimal 1 kali dalam sebulan bertempat di rumah warga dengan jenis layanan sebagai berikut,

Tabel 2. Jenis Layanan di Posyandu

\begin{tabular}{ll}
\hline No. & Jenis Layanan \\
\hline 1 & Pemeliharaan kesehatan bayi dan balita, \\
\hline 2 & Penimbangan bulanan \\
\hline 3 & Pemberian makanan tambahan \\
\hline 4 & imunisasai bagi bayi 0-11 bulan \\
\hline 5 & $\begin{array}{l}\text { Pemberian oralit untuk penanggulangan } \\
\text { diare }\end{array}$ \\
\hline 6 & $\begin{array}{l}\text { Pengobatan penyakit sebagai pertolongan } \\
\text { pertam }\end{array}$ \\
\hline Sumber:www.Indonesia-Publichealt.com,2020
\end{tabular}


Posyandu Tanjung sendiri
merupakan salah satu posyandu
berprestasi di Jawa Timur. Pada tahun
2020 posyandu Tanjung tengah bersaing dengan Posyandu Kota Malang dan Pasurun di tingkat provinsi untuk bisa mewakili Jawa Timur dalam lomba posyandu Nasional. Posyandu Tanjung dipilih karena memiliki beragam inovasi dalam layananya. Sementara itu, Posyandu Delima berada di RW 03 Kelurahan Madyopuro Kota Malang. Sejak tahun 1995 Posyandu Delima telah memberikan pelayanan terhadap warga RW 03. Pada saat itu, Posyandu Delima hanya memiliki pelayanan untuk kesehatan ibu hamil dan kontrol perkembangan bayi dan balita.

Tahun 2010, Posyandu Delima berkembang menjadi Taman Posyandu Delima. Itu berarti layanan diberikan lebih banyak, yakni Posyandu, Bina Keluarga Balita (BKB), dan Pendidikan Anak Usia Dini (PAUD). Perkembangan tersebut diawali dengan adanya rembug warga untuk mendirikan PAUD. Atas dasar inisiasi warga tersebut, maka terbentuklah PAUD di lingkungan RW 03. Adanya PAUD tersebut yang menjadikan Posyandu Delima berkembang menjadi Taman Posyandu Delima.

\section{Partisipasi Masyarakat}

Demi meningkatkan kesejahteraan masyarakat Indonesia, selama ini pemerintah berusaha mengembangkan berbagai macam program yang dapat menjangkau seluruh lapisan masyarakat, terutama bagi masyarakat yang berada pada lapisan paling bawah. Kenyataannya, selama ini program pemerintah dalam pengembangannya telah dirancang dan diputuskan dalam bentuk konsep, dan hanya mempertimbangkan dari lapisan atas masyarakat, tanpa mempertimbangkan latar belakang ekonomi, sosial, dan budaya, sehingga program yang ada cenderung tidak tepat sasaran. Oleh karenanya, keterlibatan peran masyarakat secara luas guna mendukung kesuksesan terwujudnya program merupakan hal yang sangat penting. Dibutuhkannya lembaga dalam masyarakat yang dapat mempengaruhi, memberi contoh, serta menggerakkan keterlibatan masyarakat, agar dapat mempengaruhi persepsi individu dalam kegiatan program kesejahteraan tertentu.

Partisipasi merupakan kontribusi yang melibatkan emosi dan mental individu dalam suatu kelompok dengan berbagi tanggung jawab bersama untuk mencapai tujuan kelompok yang di dalamnya terdapat perasaan sukarela dan senang demi pencapaian tujuan kelompok (Davis, 1967). Parisipasi dapat dipengaruhi juga oleh lingkungan, budaya, pengalaman, dan karakteristik organisasi. Partisipasi yang dilakukan oleh individu juga dapat berarti sebagai tindakan individu dalam mengambil bagian dalam suatu kegiatan dengan tujuan untuk mendapatkan manfaat (Theresia, Andini, Nugraha, \& Mardikanto, 2014). Wilcox (Theresia et al., 2014) berpendapat lain mengenai tahapan partisipasi, terdapat lima tahapan partisipasi, yakni: Wilcox (Theresia et al., 2014) berpendapat bahwa terdapat tahapan-tahapan partisipasi yang perlu diperhatikan, antara lain: (1) memberikan informasi, (2) konsultasi, (3) pengambilan keputusan bersama, (4) bertindak bersama, (5) memberikan dukungan. 
Tahapan yang pertama adalah tahapan memberikan informasi sekaligus konsultasi, dalam kasus posyandu ini alur informasi antara masyarakat dengan pemerintah berjalan secara dua arah. Pemerintah bisa memberikan informasi tentang kesehatan ibu dan anak melalui kader, bidan, petugas PLKB maupun pendamping. Misalnya informasi tentang gizi, KB, persalinan, dan lain sebagainya. Sementara informasi dari masyarakat kepada pemerintah berupa informasi kondisi kesehatan mereka (ibu dan anak). Informasi ini penting untuk diolah menjadi data yang nantinya penting untuk pembuatan kebijakan dalam idang kesehatan khususnya ibu dan anak. Dalam kounikasi dua arah ini juga terjalin konsultasi antara masyarakat dengan kader dan petugas kesehatan seperti bidan dan pendamping. Seperti misalnya konsultasi tentang pemilihan metode $\mathrm{KB}$ bagi ibu setelah persalinan atau konsultasi tentang perbaikan gizi pada anak.

Berikut hasil wawancara yang dilakukan dengan ketua Posyandu Tanjung Kota Madiun:

"Kader posyandu, bidan, PLKB (Petugas Lapangan Keluarga Berencana) berperan memberikan pengarahan terkait imunisasi dan informasi berkaitan dengan kesehatan anak dan ibu, dan pendamping"(HT. 13-18. 040620)

"Partisipasi masyarakat sangat aktif dan baik dalam mendukung seluruh kegiatan yang dilaksanakan oleh pihak Posyandu." (HT. 102-103. 040620)

Partisipasi yang sama juga terjadi di Posyandu Delima Kota Malang seperti yang disampaikan oleh SM sebagai berikut:
"Iya, para kader Posyandu dan masyarakat saling bekerjasama dalam menginfokan update mengenai kesehatan ibu hamil dan balita di sekitar rumah mereka."(SM. 107-108. 070720)

Pada masa pandemic covid 19 seperti saat ini ternyata juga memberian ruang partisipasi bagi kader posyandu untuk turut memberikan informasi tentang protokol kesehatan kepada masyarakat. Seperti yang dilakukan oleh kader Posyandu Delima Kota Malang seperti yang disampaikan oleh SM berikut:

"Keuntungannya adalah pengetahuan bagi diri sendiri. Contohnya adalah pengetahuan dan materi-materi mengenai kesehatan seperti mencuci tangan yang baik dan benar. Sehingga ketika pandemi COVID-19 para kader yang sudah mendapatkan pelatihan dan materi kesehatan bisa ikut turut serta menjadi tutor bagi masyarakat sekitar. Bu Sumarli juga merasa diuntungkan dengan kegiatan pelatihan dan materi-materi kesehatan lainnya seperti Pelatihan Kader Dasar, Pelatihan Kader Jumantik, dan Pelatihan Kader Pendamping Minum Obat." (SM. 183189. 080720)

Berdasarkan hasil wawancara tersebut, kegiatan yang cukup aktif dapat menumbuhkan dan mengembangkan partisipasi individu dilatar belakangi oleh motivasi, ide, dorongan, gagasan, tekanan, dan kebutuhan. Upaya-upaya yang melatarbelakangi partisipasi individu tersebut salah satunya dapat dilakukan melalui pengambilan keputusan terhadap suatu program kegiatan. Menurut Wilcox (Theresia et al., 2014) pengambilan keputusan merupakan upaya dalam memberikan dukungan, terhadap ide, gagasan yang muncul, rencana, dan 
pilihan-pilihan yang dapat mengembangkan peluang yang diperlukan untuk mengambil keputusan. Oleh karenanya, tumbuhnya partisipasi yang tinggi antar masyarakat, kader dan petugas kesehatan di posyandu muncul ide-ide yang cukup menarik dan unik, yaitu adanya inovasi program yang diambil dari keputusan bersama dari seluruh masyarakat dan kader. Ide-ide tersebut yang pada akhirnya melahirkan berbagai inovasi di posyandu yang telah dijelaskan di sub bab sebelumnya. Ide tersebut secara murni lahir dari masyarakat dan dilaterbelakangi oleh kebutuhan yang berkaitan langsung dengan mereka. Seperti yang terjadi di Posyandu Delima berikut:

"Munculnya ide dan inovasi tersebut biasanya ketika para ibu-ibu kader dan PKK sedang berkumpul santai maupun saat melakukan kegiatan Taman Posyandu dan PKK." (SM. 69-70. 080720)

Keikutsertaan atau partisipasi yang dilakukan juga akan memberikan sejumlah manfaat untuk diri sendiri. Manfaat-manfaat tersebut, dapat berupa ekonomi dan non-ekonomi (kebersamaan, persahabatan, dan pertemanan), yang mana merupakan hasil dari bertindak bersama dengan para anggota dari suatu kegiatan program tertentu. Wilcox (Theresia et al., 2014) mengemukakan bahwa bertindak bersama adalah upaya yang tidak hanya diambil dari pengambil keputusan bersama, tetapi juga hasil dari keikutsertaanindividu dalam mengimplementasikan kegiatan bersama. Hal tersebut, dapat kita peroleh setelah bertindak bersama untuk mencapai tujuan. Sejumlah manfaat juga diperoleh dari kegiatan posyandu Tanjung Kota
Madiun. Berikut kutipan wawancara yang diperoleh dari HT

“Gini bu ini kan sebanarnya niatnya memang melayani masyarakat, kemudian juga niatnya ibadah, cari pengalaman, terus banyak teman, kalo banyak teman kan suka bercanda bu jadi ini bikin awet muda..." (HT. 130-132. 040620)

Sementara diPosyandu Delima, terlihat partisipasi aktif dari semua kader, ibu-ibu, serta lansia. Partisipasi aktif yang ditunjukkan tersebut, didasarkan oleh komitmen yang kuat di antara kader, ibuibu, serta lansia untuk tetap menghidupkan Posyandu Delima. Komitmen adalah sebuah sikap suatu tingkatan yang menunjukkan keterlibatan individu dalam organisasi. Menurut (Meyer, J.P., \& Allen, 1990) konsep komitmen diidentifikasikan dengan keikatan individu yang berorientasi pada afektif atau emosional pada individu dengan adanya pengidentifikasian, keterlibatan, serta keinginan puntuk tetap menjadi anggota organisasi. Oleh karena itu, komitmen yang tinggi akan selalu sejalan dengan partisipasi aktif dari individu. Dalam hal ini, selain komitmen Posyandu Delima juga memiliki dukungan yang cukup besar dari masyarakat, termasuk RT, perguruan tinggi, dinas kesehatan, dan pemerintah kota. Dukungan yang diberikan juga bermacammacam di antaranya adalah sumbangan, pelatihan, tenaga, dan fasilitas alat-alat kesehatan.

"Anggaran kegiatan Posyandu melibatkan iuran dari tiap-tiap RT yang warganya masing-masing membayar sebesar Rp. 15.000, maupun mendapatkan SUSU TANTE (Sumbangan Sukarela Tanpa Tekanan) dari para warga datang yang 
mendapatkan layanan di Posyandu Delima. Para kader masing-masing menyisihkan sebesar Rp. 10.000 dari uang transportnya untuk menambah anggaran kegiatan Posyandu maupun ketika melakukan kunjungan ke rumah ibu hamil." (SM.118124. 080720).

"Anggaran dari pemerintah melalui Dinas Kesehatan juga turut diberikan kepada Posyandu seperti untuk program PMT (Pemberian Makanan Tambahan) Pemulihan, yaitu ATIKA (Ati, Telur, dan Ikan). Untuk anggaran uang diberikan kepada kader posyandu sebagai uang transport dari Pemerintah Kota Malang sebesar Rp. 330.000/3 bulan yang diberikan langsung ke rekening para kader. PAUD Posyandu Delima juga sudah terdaftar dalam Diknas Malang sehingga masuk ke dalam anggaran Pemerintah Kota Malang dan mendapatkan BOP (Biaya Operasional)" (SM.126-133.080720).

"Ada, seperti sumbangan donasi buku mengenai kesehatan dari mahasiswa Universitas Wisnuwardhana Malang, bantuan bibit tanaman dan pengolahan pupuk, dan APE (Alat Permainan Edukatif) untuk di BKB dan PAUD Posyandu Delima. Mahasiswa PGSD Universitas Negeri Malang juga turut melakukan pengajaran untuk anak-anak di sekitar Posyandu Delima. PKK Kota Malang juga ikut menyumbang APE. Posyandu Delima juga memiliki rekanan dengan sebuah toko bangunan yang ikut memberikan sumbangan sebesar Rp. 500.000/bulan selama 2 tahun saat awal pendirian PAUD Posyandu Delima." (SM.136-145.080720).
Dukungan dari masyarakat, pemerintah dan juga donator juga terjadi di Posyandu Tanjung Kota Madiun seperti yang disampaikan oleh HT sebagai berikut:

"Kan itu bu kita ini tiap RT kan ada namanya arisan RT...dari sana uangnya . per RT itu menyetor 30 ribu setiap bulan. Kalau dari kelurahan bantuan tidak berupa uang, namun berupa barang (kursi dan timbangan). Kita juga adabantuan dari donator..donaturnya dari masyarakat sendiri secara sukarela memberikan uang ke posyandu." (HT.126-134.040620).

Dari hasil analisis tersebut, dapat terlihat dua model partisipasi masyarakat dalam pelayanan posyandu di Kota Madiun dan Kota Malang. Model ini dapat digambarkan dalam bentuk berikut,

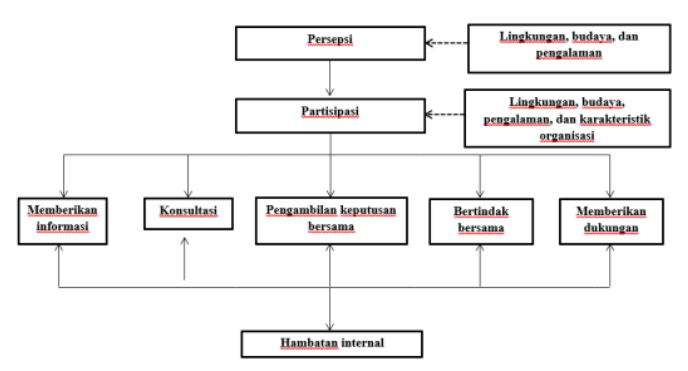

Gambar 1. Model Partisipasi Masyarakat Pada Layanan Posyandu Kota Madiun Sumber: hasil olah data peneliti

Sementara itu, untuk model partisipasi masyarakat pada layanan posyandu di Kota Malang dapat tergambarkan dalam bentuk berikut ini, 


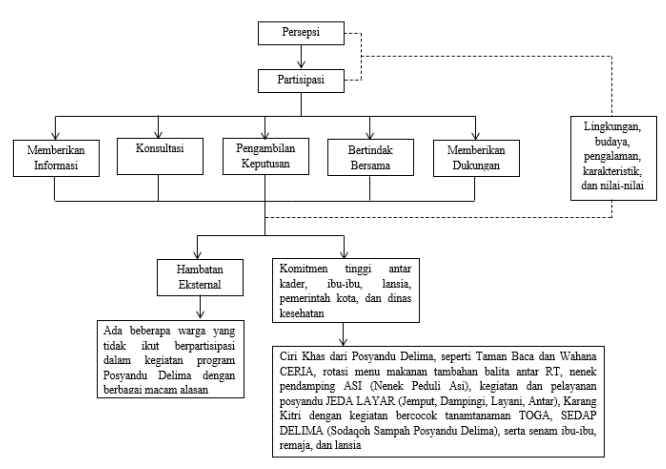

Gambar 2. Model Partisipasi Masyarakat Pada Layanan Posyandu Kota Malang Sumber: hasil olah data peneliti

Pelibatan masyarakat dalam pelayanan publik bukanlah sesuatu yang mudah dijalankan. Kondisi ini membutuhkan partisipasi dan kesadaran masyarakat yang tinggi. Dalam konteks governance keterlibatan masyarakat sebagai aktor dalam pemerintahan menunjukkan posisi yang setara antara pemerintah, masyarakat, dan swasta. Nyatanya tidak semua masyarakat menerima konsep idel tersebut. sebagain masyarakat menikmati posisinya hanya sebagai penerima layanan dan bertindak pasif. Sebagain dari mereka menilai bahwa pelayanan publik wajib dijalankan oleh pemerintah dan memandang partisipasi bukanlah suatu keharusan.

Hambatan sekaligus tantangan utama dari pelayanan berbasis partisipasi adalah bagaimana menggerakan masyarakat itu sendiri. Partisipasi dipahami sebagai tindakan yang tidak bersifat wajib atau bukan keharusan, mengandung tindakan sukarela, sehingga warga memiliki pilihan untuk berpartisipasi atau tidak. Dalam konteks ini pemerintah tidak bisa memaksakan warganya yang bisa dilakukan hanya sebatas himbauan dan pendekatan untuk meningkatkan partisipasi masyarakat dalam pelayanan publik. Kegigihan dan partisipasi aktif yang dilakukan oleh seluruh anggota posyandu termasuk kader, ibu-ibu, lansia, serta masyarakat dalam mengatasi setiap hambatan atau permasalahan yang muncul telah membuahkan hasil berupa capaian keberhasilan dari pelayanan posyandu.

Oleh karenanya, keterlibatan peran masyarakat secara luas guna mendukung kesuksesan terwujudnya program merupakan hal yang sangat penting. Dibutuhkannya lembaga dalam masyarakat yang dapat mempengaruhi, memberi contoh, serta menggerakkan keterlibatan masyarakat, agar dapat mempengaruhi persepsi individu dalam kegiatan program kesejahteraan tertentu.

Davidoff (Lestari, 2007) mengemukakan bahwa persepsi merupakan suatu proses yang rumit dan aktif dengan melibatkan sistem sensorik dan otak. Persepsi manusia ini dapat berubah-ubah dan dapat menyesuaikan diri sesuai dengan stimulusnya, misalnya lingkungan, kebudayaan, dan pengalaman, yang mana ketiga hal tersebut diproses dalam level kognitif masing-masing individu. Dengan demikian, persepsi merupakan kolaborasi dari hasil interaksi antara individu sebagai bagian dari masyarakat, lokasi geografis, latar belakang sosial, ekonomi, politik, dan budaya, serta kepercayaan yang dianutnya. Oleh karena itu, persepsi yang dihasilkan oleh setiap individu akan berbeda tergantung pada cara individu dalam menyikapi dinamika yang terjadi dalam diri individu pada saat menerima stimulus dari luar diri, yang melibatkan indera dan emosi, yang mana hal itu akan diorganisir, diseleksi, dan diinterpretasi 
secara berbeda oleh setiap individu, sehinga memunculkan pemaknaan tertentu terhadap sesuatu.

Masing-masing individu memiliki dua macam pemaknaan persepsi dalam diri mereka, yaitu makna positif dan makna negatif (Lestari, 2007). Makna positif dan negatif akan menjadi pendorong dan penghambat bagi individu untuk berinteraksi, berkontribusi, dan berpartisipasi pada kehidupan bermasyarakat. Individu sebagai bagian dari masyarakat, hendaknya memiliki pemaknaan persepsi yang positif, agar dapat berpartisipasi secara aktif dalam kehidupan bermasyarakat.

Partisipasi merupakan kontribusi yang melibatkan emosi dan mental individu dalam suatu kelompok dengan berbagi tanggung jawab bersama untuk mencapai tujuan kelompok yang di dalamnya terdapat perasaan sukarela dan senang demi pencapaian tujuan kelompok (Davis, 1967). Parisipasi dapat dipengaruhi juga oleh lingkungan, budaya, pengalaman, dan karakteristik organisasi. Partisipasi yang dilakukan oleh individu juga dapat berarti sebagai tindakan individu dalam mengambil bagian dalam suatu kegiatan dengan tujuan untuk mendapatkan manfaat (Theresia, Andini, Nugraha, \& Mardikanto, 2014). Wilcox (Theresia et al., 2014) berpendapat lain mengenai tahapan partisipasi, terdapat lima tahapan partisipasi, yakni: Wilcox (Theresia et al., 2014) berpendapat bahwa terdapat tahapan-tahapan partisipasi yang perlu diperhatikan, antara lain: (1) memberikan informasi, (2) konsultasi, (3) pengambilan keputusan bersama, (4) bertindak bersama, (5) memberikan dukungan.
Setelah berbicara mengenai tahapan partisipasi, tentu tidak dapat terlepas dari program yang bertujuan untuk mendapatkan manfaat dan menumbuhkan partisipasi pada individu, adapun program di Indonesia yang cukup bermanfaat dan berbasis kekeluargaan, antara lain program posyandu. Program posyandu telah lama digaungkan oleh pemerintah demi meningkatkan kemampuan masyarakat untuk mengembangkan kegiatan-kegiatan kesehatan yang dapat meningkatkan kesehatan masyarakat.

Dalam penelitian ini, kebutuhan akan informasi sangat dibutuhkan oleh seluruh masyarakat. Menurut Wilcox (Theresia et al., 2014) suatu kelompok yang cukup dekat dengan lapisan masyarakat, dapat memberikan pengetahuan dan informasi kepada masyarakat. Posyandu Tanjung Kota Madiun sebagai suatu program yang cukup dekat dengan masyarakat cukup bagus dalam memberikan kebutuhan akan informasi bagi masyarakat dalam masa pandemi Covid-19 ini, karena kegiatan posyandu Tanjung Kota Madiun masih tetap berjalan, kader tetap memberikan PMT (makanan tambahan) kepada balita dengan memberikan langsung di rumah dan pelayanan posyandu juga diadakan satu kali dalam satu bulan bertempat di salah satu rumah kader karena tidak adanya gedung/tempat khusus untuk posyandu, yang mana pemberian informasi tersebut dilakukan oleh kader posyandu, bidan, petugas lapangan keluarga bencana (PLKB), dan pendamping. Kegiatan yang cukup aktif dilakukan oleh para pengurus posyandu dengan partisipasi individu sebagai anggota dari posyandu juga baik, sehingga 
dukungan akan kegiatan posyandu cukup baik.

\section{SIMPULAN}

Partisipasi merupakan kontribusi yang melibatkan emosi dan mental individu yang melibatkan proses tanggung jawab bersama untuk mencapai tujuan kelompok yang diharapkan. Pelibatan proses mental ini dipengaruhi juga oleh lingkungan, budaya, pengalaman, dan karakteristik organisasi.Berdasarkan hasil penelitian dan pembahasan yang telah dikemukakan,dapat disimpulkan bahwa kegiatan yang cukup aktif pada posyandu dapat menumbuhkan dan mengembangkan partisipasi individu dilatar belakangi oleh motivasi, ide, dorongan, gagasan, tekanan, dan kebutuhan. Tumbuhnya partisipasi yang tinggi di masyarakat, kader dan petugas kesehatan di posyandu dapat memunculkan ide-ide inovasi program yang diambil dari keputusan bersama dari seluruh masyarakat dan kader.

\section{DAFTAR PUSTAKA}

Alsabrina, 2019, Anak Nusantara Alami Gizi Buruk, Indonesia Tempati Ranking 5 Stunting di Dunia, Tabloid Nova 30 Januari 2019, diakses melalui laman https://nova.grid.id/read/051619792/anak -nusantara-alami-gizi-buruk-indonesiatempati-ranking-5-stunting-didunia?page=all pada 20 Januari 2020

Basyari, I.W., 2014, Nilai-Nilai Kearifan Lokal (Local Wisdom) Tradisi Memitu Pada Masyarakat Cirebon (Studi Masyarakat Desa Setupatok Kecamatan Mundu). Jurnal Edunomic, Volume 2 No. 1 Tahun 2014 diakses melalui laman https://media.neliti.com/media/publication s/271651-nilai-nilai-kearifan-lokal-localwisdom-382be5b5.pdf pada 20 Januari 2019. Budiardjo, M., 2008, Pengantar Ilmu Politik, Gramedia Pustaka Utama, Jakarta.
Creswell, John W., 1998, Qualitative Inquiry and Rearch Design : Choosing Among FiveTraditions, SAGE Publications, Inc., Thousand Oaks, California.

Dinas Kesehatan Provinsi Jawa Timur, 2018, Profil Kesehatan Provinsi JAwa Timur Tahun 2018, Dinas Kesehatan Provinsi Jawa Timur, Surabaya.

Iswarawanti, D.N., Kader Posyandu: Peranan dan Tantangan Pemberdayaannya dalam Usaha Peningkatan Gizi Anak di Indonesia. Jurnal Manajemen Pelayanan Kesehatan, Volume 3 No. 042010 Hlm. 168-173.

Kementerian Kesehatan Republik Indonesia, 2018, Data dan Informasi Profil Kesehatan Indonesia 2017, Kementerian Kesehatan Republik Indonesia, Jakarta.

Kementerian Kesehatan Republik Indonesia, 2019, Data dan Informasi Profil Kesehatan Indonesia 2018, Kementerian Kesehatan Republik Indonesia, Jakarta.

Mahmudi, 2015, Manajemen Kinerja Sektor Publik, Unit Penerbit dan Percetakan Sekolah Tinggi Ilmu Manajemen, Yogyakarta.

Marijan, K., 2015, Sistem Politik Indonesia, Prenadamedia Group, Jakarta.

Moustakas, C., 1994, Phenomenological Research Methods, SAGE Publications, Inc., Thousand Oaks, California.

Sedarmayanti, 2013, Reformasi Administrasi Publik, Reformasi Birokrasi, dan Kepemimpinan Masa Depan, Refika Aditama, Bandung.

Shusmita, 2020, Posyandu di Kota Madiun Berpeluang Terbaik se-Jatim, Madiun Pos 6 Januari 2020, diakses melalui laman http://www.madiunpos.com/posyandu-dikota-madiun-berpeluang-terbaik-se-jatim1040045 pada 20 Januari 2020

Verawati, A., \& Affandi, I., 2016, Implementasi Nilai-Nilai Kearifan Lokal Dalam Mengembangkan Keterampilan Kewarganegaraan (Studi Deskriptif Analitik Pada Masyarakat Talang Mamak Kec. Rakit Kulim, Kab. Indragiri Hulu Provinsi Riau), Jurnal Pendidikan Ilmu Sosial, Volume 25, No. 1, Edisi Juni 2016.

Yunus, R, 2014, Nilai-Nilai Kearifan Lokal (Local Genius) Sebagai Penguat Karakter Bangsa: Studi Empiris Tentang Huyula, Deepublish, Sleman. 